University of Montana

ScholarWorks at University of Montana

$1-2010$

\title{
Small-Mammal Seed Predation Limits the Recruitment and Abundance of Two Perennial Grassland Forbs
}

\author{
Mary Bricker \\ Dean Pearson \\ John L. Maron \\ University of Montana - Missoula, john.maron@mso.umt.edu
}

Follow this and additional works at: https://scholarworks.umt.edu/biosci_pubs

Part of the Biology Commons

Let us know how access to this document benefits you.

\section{Recommended Citation}

Bricker, Mary; Pearson, Dean; and Maron, John L., "Small-Mammal Seed Predation Limits the Recruitment and Abundance of Two Perennial Grassland Forbs" (2010). Biological Sciences Faculty Publications. 234. https://scholarworks.umt.edu/biosci_pubs/234

This Article is brought to you for free and open access by the Biological Sciences at ScholarWorks at University of Montana. It has been accepted for inclusion in Biological Sciences Faculty Publications by an authorized administrator of ScholarWorks at University of Montana. For more information, please contact scholarworks@mso.umt.edu. 


\title{
Small-mammal seed predation limits the recruitment and abundance of two perennial grassland forbs
}

\author{
Mary Bricker, ${ }^{1,3}$ Dean Pearson, ${ }^{1,2}$ and John Maron ${ }^{1}$ \\ ${ }^{1}$ Division of Biological Sciences, University of Montana, Missoula, Montana 59812 USA \\ ${ }^{2}$ Rocky Mountain Research Station, USDA Forest Service, 800 East Beckwith Avenue, Missoula, Montana 59801 USA
}

\begin{abstract}
Although post-dispersal seed predators are common and often reduce seed density, their influence on plant population abundance remains unclear. On the one hand, increasing evidence suggests that many plant populations are seed limited, implying that seed predators could reduce plant abundance. On the other hand, it is generally uncertain whether the magnitude of seed limitation imposed by granivores is strong enough to overcome densitydependent processes that could compensate for seed loss at later stages. We examined the impact of seed predation by small mammals, primarily deer mice (Peromyscus maniculatus), on seedling recruitment and subsequent plant establishment of two perennial grassland forbs in western Montana, USA: Lupinus sericeus (Fabaceae) and Lithospermum ruderale (Boraginaceae). The experiment combined graded densities of seed addition for each species with a small-mammal exclusion treatment. Seedling recruitment and plant establishment were monitored in the experimental plots for up to three years. For both species, small-mammal exclusion increased the total number of seedlings that emerged, and these effects were still significant three years after seed addition, resulting in greater numbers of established plants inside exclosures than in control plots. We also found evidence of seed limitation, with increasing density of seeds added leading to increased numbers of seedlings. Results from seed addition and small-mammal exclusion experiments in later years also revealed significant impacts of small mammals on seedling emergence. These results suggest that granivores can have potentially important impacts in limiting forb abundance in grasslands communities.
\end{abstract}

Key words: forb abundance; granivory; grassland communities; Lithospermum ruderale; Lupinus sericeus; Peromyscus maniculatus; seed predation, limitation, and addition; small mammal.

\section{INTRODUCTION}

Small-mammal seed predators are common in many ecological systems, and due to their high metabolic rates they can consume large numbers of seeds relative to their mass or numbers (Reichman 1979, Brown and Munger 1985, Hulme 1993, 1998). Many studies on small-mammal granivory have examined the details of seed predator behavior, quantifying how factors such as cover type, season, and seed characteristics (e.g., size, density, or nutrient concentration) influence seed loss. These studies have shown that rodents generally target larger, more nutrient-rich seeds (Mittelbach and Gross 1984, Brown and Munger 1985, Hoffman et al. 1995, Celis-Deiz et al. 2004), and that seed loss can be strongly influenced by habitat or vegetation cover (Mittelbach and Gross 1984, Hulme 1993, Manson and Stiles 1998, Maron and Kauffman 2006), seed density (Hulme 1993, 1994), and abundance of these rodents (Pearson and Callaway 2008). We know that large numbers of seeds can be removed by seed predators, and in some cases we can even make reasonable predictions about which plant

Manuscript received 26 September 2008; revised 13 April 2009; accepted 16 April 2010. Corresponding Editor: R. J. Marquis.

${ }^{3}$ E-mail: mary.bricker@mso.umt.edu species and communities are most likely to sustain heavy seed predation. Yet surprisingly little is known about the degree to which seed predation affects plant recruitment and longer term patterns of plant abundance.

Theory generally predicts that seed predation should have the greatest impact on plant numbers when populations are more strongly seed limited as opposed to microsite limited (Harper 1977, Crawley 2000). When recruitment is seed limited, seed number and seedling numbers are directly correlated. Thus, any consumerdriven decrease in seed abundance translates directly to a decrease in recruitment. In contrast, when populations are microsite limited, the relationship between seed availability and seedling recruitment is decoupled. The magnitude of seedling recruitment is then governed by the availability of safe sites for germination rather than the density of seeds (Harper 1977, Eriksson and Ehrlen 1992, Clark et al. 2007). Thus, when plant populations are safe-site limited, seed loss to consumers does not necessarily translate to reductions in subsequent seedling recruitment.

The few examples of post-dispersal seed predators affecting plant abundance come mostly from desert and dune systems, where there is relatively little established vegetation. Experimental studies have demonstrated that granivores can affect plant abundance in coastal dune 
habitats (Kauffman and Maron 2006) and plant community structure in desert systems (Brown et al. 1979, Inouye et al. 1980, Davidson et al. 1984, Brown and Heske 1990). In a restoration context, experiments that have excluded rodents from planted prairie or wetgrassland sites have also shown impacts of granivores and herbivores on species composition (Edwards and Crawley 1999, Howe and Brown 2000, 2001, Howe and Lane 2004, Howe et al. 2006). Yet in habitats with greater cover and within intact vegetation, smallmammal granivores might have much less influence on plant abundance. For instance, Maron and Kauffman (2006) found differences in the impact of seed predation on seedling recruitment in adjacent dune and grassland habitats despite similar densities of small mammals. Reader (1993) showed that large-seeded species, those most vulnerable to predation, survived seed predation better when cover (live vegetation and litter) was present, but that cover was also a key factor inhibiting seedling emergence. These results suggest that the relative importance of seed predation and safe sites may shift in higher cover environments, but most long-term work has been done in arid habitats with relatively low vegetative cover. We know much less about whether plant populations are limited by smallmammal seed predation in communities with more established vegetation, where there may be greater competition for suitable germination sites, as well as less of a chance for small mammals encountering seeds.

Although there have now been a host of seed-addition experiments aimed at understanding the scope for changes in seed availability to alter plant abundance, experiments of this sort often have three major shortcomings. First, in most of these studies, seed addition is done without manipulating consumer pressure (Turnbull et al. 2000, Clark et al. 2007). In this case, if seeds added to plots are subsequently (but "invisibly") eaten by consumers, this can wipe out initial experimentally imposed differences in seed density. As a result, one may find no relationship between seed density and seedling recruitment, and falsely conclude that a population is micro-site rather than seed limited, when in fact the reverse might be the case. Second, seed addition experiments rarely follow individuals past the season in which they emerge (Turnbull et al. 2000, Clark et al. 2007). Thus, these experiments often do not effectively measure negative density-dependent survival that could compensate for seed loss. Finally, most seed addition experiments only add a single density of seeds to plots. In a recent meta-analysis of seed addition experiments Clark et al. (2007) found that only $26 \%$ of seed addition studies used more than one density of seeds. With only one seed density, usually compared to a zero-seed treatment, it is difficult to determine how variation in seed loss (imposed on variable seed production or availability) might translate into changes in seedling recruitment. While experiments and reviews examining evidence of seed limitation from a range of species in seed addition experiments have shown that seed limitation might be more prevalent than generally thought (Eriksson and Ehrlen 1992, Turnbull et al. 2000), it has also been asserted that seed limitation is of relatively minor importance compared with other factors that would limit the establishment of seedlings (Clark et al. 2007, Poulsen et al. 2007).

Critical assessment of the impacts of seed predators on plant population dynamics requires examining several key factors. The first of these involves determining whether granivores limit seedling recruitment. For this to occur, a plant population must be seed limited, so that reductions in seed abundance translate to lowered seedling recruitment. The second factor that must be determined is whether processes at later life stages, such as density-dependent mortality, compensate for initial differences in seedling abundance due to seed predation. Compensatory density dependence acting on seedling survival could reduce or even eliminate any difference in seedling numbers that results from greater recruitment when seeds are protected from granivores (Harper 1977, Howe and Brown 2001, Halpern and Underwood 2006). To date, most research on this topic has examined one but not both of these factors. For example, experiments have generally either explored seed limitation by seed addition without consumer manipulation, or examined post-dispersal seed predation without manipulating seed density. To gain a better understanding of the contexts in which seed predators will be most important, or to understand how seed limitation mediates the realized impact of seed loss in populations, it will be important to unite the two concepts and approaches in studies that can address both issues at once. This combined experimental approach has been rare, especially in natural systems, and it has been particularly rare for the fate of seedlings to be followed past emergence (but see Maron and Simms 1997, Edwards and Crawley 1999, Pearson and Callaway 2008). This study examines both seed limitation and seed predation in a natural setting, to assess how post-dispersal seed predation affects plant abundance.

In this study we used a series of experiments crossing small-mammal exclosure treatments with seed addition at a range of seed densities to address the following questions: (1) Is seedling recruitment for two species of heavy-seeded perennial forbs, Lithospermum ruderale and Lupinus sericeus, significantly depressed by postdispersal seed predation from small mammals? (2) How seed limited are these plant populations, and how does the degree of seed limitation change in the presence and absence of small-mammal seed predators? (3) Do smallmammal-driven changes in seedling recruitment persist, creating differences in the abundance of juvenile plants, or are any initial differences negated by subsequent density-dependent mortality?

\section{Methods \\ Study system}

Experiments took place at seven sites in semiarid grasslands in the Blackfoot Valley of western Montana, 
USA. Sites were dispersed over $\sim 50 \mathrm{~km}$ of river valley. The plant community in these grasslands is dominated by native perennial bunchgrasses (Festuca idahoensis and Festuca scabrella) and sagebrush (Artimisia tridentata) and contains a high diversity of native perennial forbs. Exotic species are present at these sites but generally occur at very low densities.

The focal plant species, Lupinus sericeus (Fabaceae) and Lithospermum ruderale (Boraginaceae) are both long-lived native perennial forbs. Aboveground growth begins in late April to early May and plants flower between May and early July. Both species are pollinated by a variety of generalist insects and set seed in July and August. These species have relatively heavy seeds (mean seed masses \pm SD: Lupinus $=0.0210 \pm 0.004496 \mathrm{~g}$; Lithospermum $=0.0211 \pm 0.005098 \mathrm{~g}$ ), which are dispersed locally around parent plants. Seeds of both species are commonly consumed by deer mice (J. Maron and D. Pearson, unpublished data). Experiments using buried seeds in bags have revealed that $L$. sericeus seeds mostly germinate during their first spring (0-2\% surviving beyond the first growing season), whereas most seeds of Lithospermum remain dormant in a seedbank for at least one year ( $>60 \%$ surviving in seed bags, and $<3 \%$ germinating in seed addition plots in the first season; M. Bricker, unpublished data).

Although several small-mammal species are present at sites (deer mice, Peromyscus maniculatus; montane voles, Microtus montanus; northern pocket gophers, Thomomys talpoides; Columbian ground squirrels, Spermophilis columbianus; and (rarely) yellow-pine chipmunks, Tamias amoenus; shrews, Sorex; and hares, Sylvagus nutallii), deer mice are the main post-dispersal seed predator. The other small-mammal species are primarily herbivorous or florivorous, insectivorous, or in the case of $S$. columbianus, inactive when seeds are being dispersed from these plants. Neither Lupinus nor Lithospermum have eliasomes on their seeds and their seeds are not dispersed by ants. Very few seeds of either species were removed when left in trays in areas accessible to birds and insects, but not to small mammals (M. Bricker, unpublished data).

Small-mammal exclosures were constructed in the spring of 2002 (at three sites) and during September 2004 (at four sites). At each site, we established one $10 \times$ $10 \mathrm{~m}$ control plot paired with one $10 \times 10 \mathrm{~m}$ smallmammal exclosure. Control and small-mammal exclosure plots were separated by a minimum of $5 \mathrm{~m}$, but were no farther apart than $20 \mathrm{~m}$. Exclosures were constructed of $0.625 \times 0.625 \mathrm{~cm}$ welded wire fencing buried to a depth of 30-40 $\mathrm{cm}$ and extending $60 \mathrm{~cm}$ above ground. Fencing was topped with $20 \mathrm{~cm}$ of aluminum flashing to prevent small mammals from climbing over fences. Exclosures prevented most smallmammal access, but we also set snap traps inside exclosures to ensure they remained free from small mammals. Over the course of the three-year study, we trapped a total of 21 mice in the seven exclosures, one- half of which were trapped immediately after snow melt in early spring. These captures likely resulted from mice gaining access in winter via snow that had built up along the fences. The small-mammal exclosures did not deter large grazing mammals present in the system; scat and tracks of elk and deer, as well as evidence of elk grazing, particularly in early spring, were clearly evident inside the small-mammal exclosures as well as outside (M. Bricker, personal observation).

\section{Seed addition experiments}

In September 2004 we added five densities of seeds of each species to $0.5 \times 0.5 \mathrm{~m}$ subplots within the seven 10 $\times 10 \mathrm{~m}$ small-mammal exclosures and paired control plots. Within each plot there were 10 seed addition subplots (two species $\times$ five seed densities), each spaced at least $0.5 \mathrm{~m}$ apart and at least $1 \mathrm{~m}$ from the perimeter of the plot. Seed addition subplots were placed randomly in experimental plots, which generally included established populations of Lupinus and Lithospermum (one of the seven sites did not have adult Lupinus present in the experimental plot, though there were naturally established populations nearby). If adult Lupinus or Lithospermum plants were present in the initially selected random location, the subplot was moved systematically along a transect within the plot until it fell on a $0.25-\mathrm{m}^{2}$ area without established adult plants. This prevented natural seed rain from falling into seed addition subplots. Each subplot received seeds of either Lupinus or Lithospermum, collected locally in 2004. Lupinus were added at densities of $0,25,50,100$, and 200 seeds per $0.25 \mathrm{~m}^{2}$; Lithospermum were added at densities of 0,50 , 100,200 , and 300 seeds per $0.25 \mathrm{~m}^{2}$. These densities were chosen to span and extend past the natural range of seed densities produced by seed rain from large individual plants of each species (Lithospermum, $138.7 \pm 20.2$; Lupinus, $78.1 \pm 7.28$; mean $\pm \mathrm{SE}$ ). Seeds were scattered over the surface of undisturbed plots; no effort was made to bury seeds or force them into the soil surface.

From April through June of 2005 we censused subplots for seedlings approximately every three weeks, and thereafter monthly in July and August. Seedlings were counted when cotyledons had emerged from the seed coat. Cotyledons of both species are large and distinct from those of other species. The cotyledons persist for some time after drying up, making seedlings generally easy to distinguish from small returning plants. At each census we marked newly emerged seedlings and recorded the number of surviving and dead seedlings from previous censuses. In the spring and summer of 2006 and 2007 we continued to census new and surviving seedlings monthly, and tracked separately the survival of the cohorts that emerged in 2005, 2006, and 2007. The cumulative emergence (the total number of seedlings that emerged in the years 2005 to 2007) and the number of plants established at the end of the final growing season (plants that had emerged and were still alive in late July 2007) were analyzed with a split-plot ANOVA 
(PROCMIXED, SAS Institute 2004). Emergence and establishment were both log-transformed in these analyses. Small-mammal exclusion treatment was a whole-plot factor, and seed density (treated as a discrete, categorical variable) was the subplot factor; site was used as blocking factor and species as a fixed factor. Taken together, these analyses are conservative because: (1) seed density was used as a categorical rather than continuous variable due to the limited number of seed densities used, and (2) unlike many other seed addition studies, zero-seeds-added subplots were not used in analyzing small-mammal and seed density impacts. We excluded zero-seeds-added subplots from the analyses because no or extremely few seedlings germinated from the resident soil seed bank. Thus, including these plots would have forced a positive relationship with seed density if any seeds germinated in seed addition plots. By excluding zero-seeds-added subplots, our results reflect the effects of seed predators on recruitment along a gradient of seed availability.

We repeated portions of these seed addition experiments in 2005 and 2006 in order to examine: (1) how seed limitation in the presence of small mammals varies across years, and (2) how seed predation and its impact on seedling recruitment vary across years. In 2005, we added seeds to a new set of 10 seed addition subplots (five densities per species $\times$ two species) outside of smallmammal exclosures. Inside the exclosures we added only one plot for each species, at a midrange density of 100 seeds. This enabled us to compare predation pressure at one seed density across years, while at the same time determining the relationship between seed input and seedling output in the presence of small mammals across years. In 2006, we repeated only the 100 -seed density, with one plot for each species, in the exclosure and control plots at each of the seven sites. As with the seeds added in 2004, we censused these seed addition plots monthly for new and surviving seedlings and juvenile plants in the summers of 2006 and 2007. Lithospermum plots set out in 2006 were also censused in the summer of 2008. To determine how seed density influenced recruitment outside of exclosures, we used PROC GLM (SAS Institute 2004), with seed density (excluding zeroseed-added plots), species and year as fixed factors, and log-transformed cumulative emergence and cumulative establishment as response variables. For the 100-seed plots in and out of exclosures, we analyzed the results with a three-way ANOVA (S-PLUS 2007), with log of emergence in following year (for Lupinus) or two years after seed addition (for Lithospermum, due to the delay in emergence from seed dormancy) as response variable and year, species, and small-mammal exclusion as fixed factors.

Because the seedlings germinated at a range of densities in seed addition plots, we were able to examine how variation in seedling and juvenile plant density affected survival. This enabled us to assess the extent to which density-dependent seedling mortality compensat- ed for seed loss to predation. To do this, we used linear regression (PROC GLM, SAS Institute 2004) to examine the influence of seedling density (total number of seedlings emerged), small-mammal treatment, and species, on mortality rates. Examining the impact of exclusion treatment on mortality rate allowed us to assess whether herbivorous small mammals, such as voles and ground squirrels, were contributing to any differences in plant abundance between exclosures and controls, and to separate the effects of granivory and herbivory. Mortality rate was calculated as a proportion for each plot by dividing the number of plants that died over the course of the experiment by the total number that had germinated. The mortality rate was arcsine square-root transformed for the regression analyses.

Results

\section{Effects of small-mammal exclusion and seed density on seedling emergence and plant establishment}

In the 2004 seed additions in and out of smallmammal exclosures at all seed densities, small-mammal exclusion increased seedling emergence in both species, with cumulative emergence averaging 2.7 times higher inside of exclosures than in control plots (Fig. 1; $F_{1,6.6}=$ 20.06, $P=0.0033)$. Three years after seed addition, the number of established plants still showed a significant impact of exclosure treatment (Fig. $1 ; F_{1,6.39}=5.90, P=$ 0.0488). There was no significant difference between species in the rate of seedling emergence $\left(F_{1,93.8}=0.55, P\right.$ $=0.4617)$ or establishment $\left(F_{1,92.1}=3.19, P=0.0774\right)$. The small-mammal exclosure by species interaction was not significant (emergence, $F_{1,94.3}=2.11, P=0.149$; establishment, $\left.F_{1,93.6}=0.99, P=0.321\right)$, nor was the exclosure by seed density interaction (emergence, $F_{3,87.8}$ $=1.8, P=0.153$; establishment, $F_{3,87.6}=0.790, P=$ $0.321)$.

Indicative of seed limitation, the number of emerged seedlings increased with increasing seed densities (Fig. 1; $\left.F_{3,87.8}=8.78, P<0.0001\right)$, and these differences were still evident three years after the initial seed addition (Fig. $1 ; F_{3,87.6}=8.23, P<0.0001$ ). Rates of emergence and establishment (plants per seed initially added) are reported in the Appendix.

\section{Effects of seed density and year sown on seedling emergence outside of small-mammal exclosures}

As was the case for the 2004 seed addition experiment, in 2005 in the presence of deer mice, cumulative seedling emergence increased with increasing seed density in the two years following seed addition (Fig. $2 ; F_{3,102}=3.32$, $P=0.0229)$. However, the magnitude of seedling emergence varied depending on the years seeds were added (i.e., 2004 vs. 2005; Fig. $2 ; F_{1,102}=8.16, P=$ 0.0052), and emergence differed between the two forb species $\left(F_{1,102}=8.44, P=0.0045\right)$. There were no significant species by year $\left(F_{1,102}=0.30, P=0.568\right)$ or species by seed density $\left(F_{3,102}=0.05, P=0.986\right)$ interactions. 

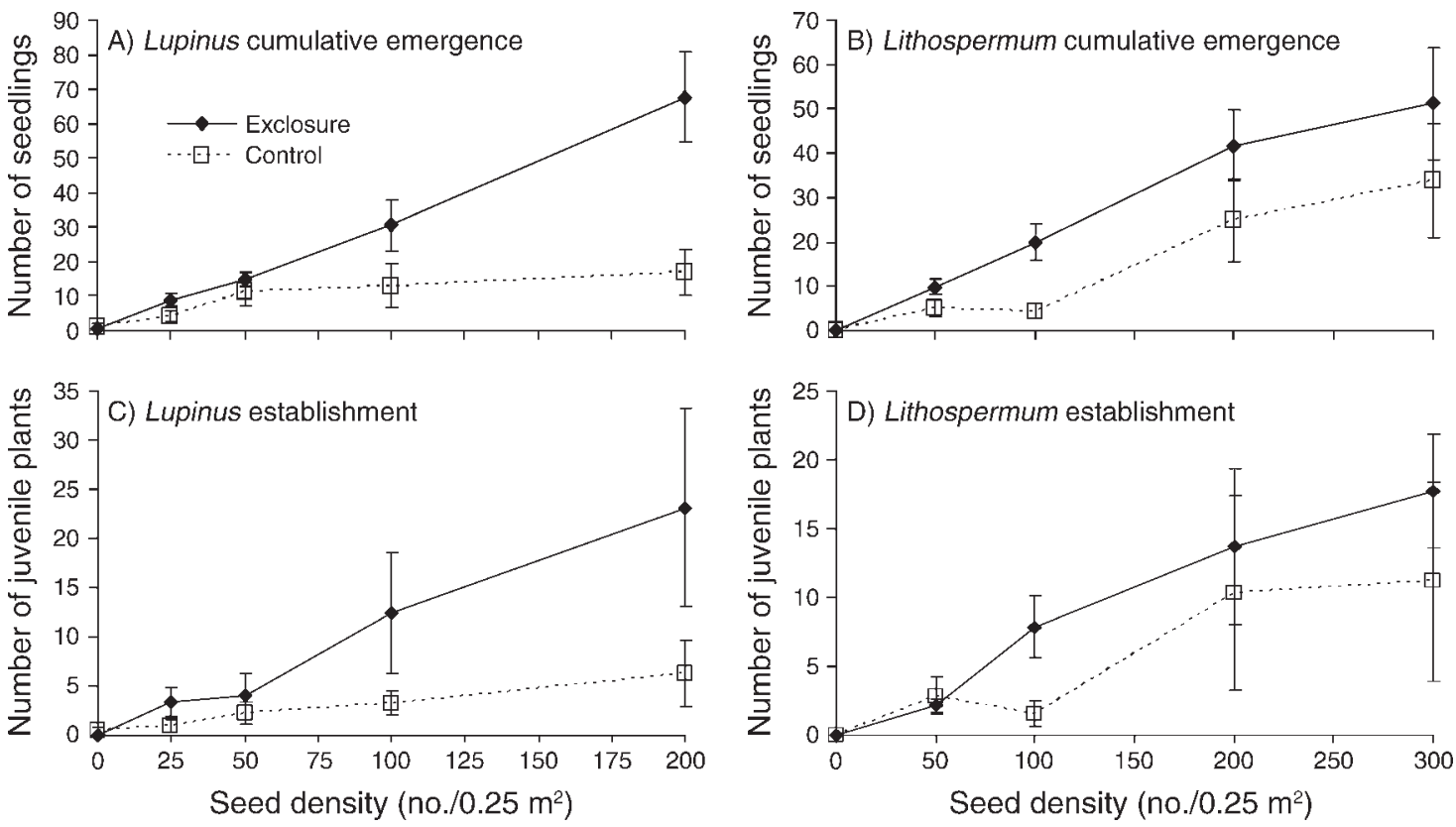

FIG. 1. Cumulative emergence (total number of seedlings emerged over three years) and establishment (number of individuals alive at end of third growing season) three years after seed addition, in and out of experimental small-mammal exclosures for (A, C) Lupinus and (B, D) Lithospermum in the Blackfoot Valley of western Montana, USA. Points show means for the seven experimental sites (error bars show $\pm \mathrm{SE}$ ).

\section{Temporal variation in effects of seed predation on seedling emergence}

The emergence of seedlings (in the year following seed addition for Lupinus, or the second year following seed addition in Lithospermum, due to the time lag in germination) in 100-seed plots in and out of smallmammal exclosures showed a significant effect of exclosure treatment (Fig. 3; $F_{1,74}=7.481, P=0.0078$ ), and species $\left(F_{1,74}=20.389, P<0.0001\right)$, but not of year seeds were added $\left(F_{2,74}=0.1710, P=0.843\right)$. None of the interactions between species, year, and exclusion treatment were significant (species $\times$ year, $F_{2,74}=0.944, P=$ 0.394 ; species $\times$ exclusion, $F_{1,74}=1.585, P=0.212$; year $\times$ exclusion, $\left.F_{2,74}=2.592, P=0.0816\right)$.

\section{Effects of density and small-mammal exclosure treatment on plant mortality rate}

Plant mortality was unaffected by the variation in plant density that resulted from adding more seeds to plots. Across the range of densities at which seedlings germinated in the experimental plots, there was no effect of seedling density on mortality rate $\left(F_{46,21}=1.32, P=\right.$ $0.25)$. Mortality rate did not differ between smallmammal exclosure and control plots $\left(F_{1,21}<0.01, P=\right.$ $0.981)$ or between species $\left(F_{1,21}=0.44, P=0.790\right)$. The interaction between small-mammal exclusion and seedling density was not significant $\left(F_{10,21}=1.43, P=0.135\right)$. Fig. 4 shows the change in the number of plants in the seed addition subplots, from the highest-density seed additions (200 seeds for Lupinus, 300 for Lithospermum).
Mortality rates by rodent treatment and initial seed density are reported in the Appendix.

\section{DisCUSSION}

Protection from seed predation led to significant increases in seedling emergence and establishment for
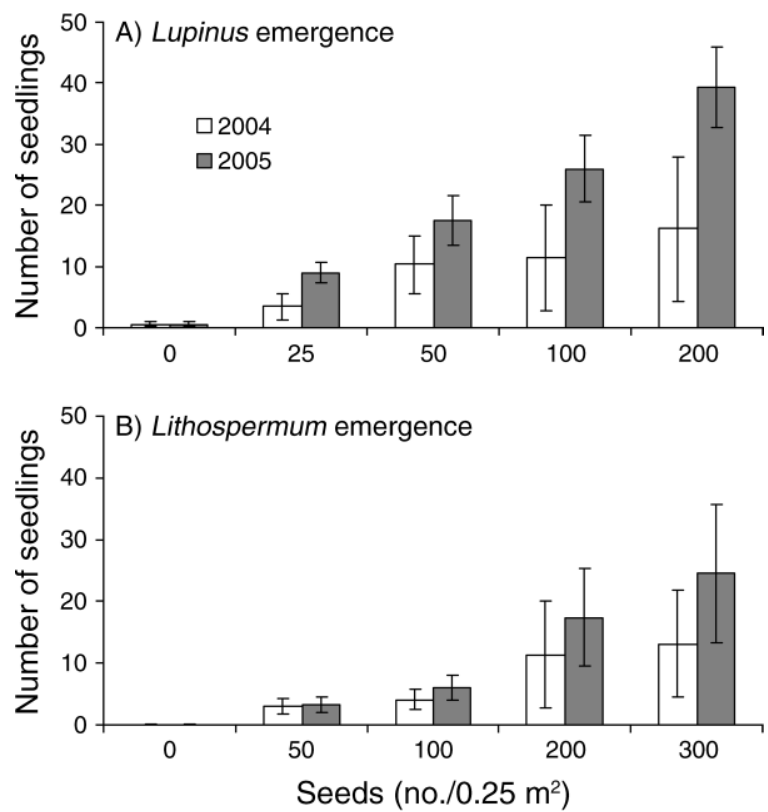

FIG. 2. Two-year cumulative emergence (total number of seedlings emerged over two seasons, mean \pm SE) for (A) Lupinus and (B) Lithospermum, for seeds added outside of exclosures in 2004 and 2005. 


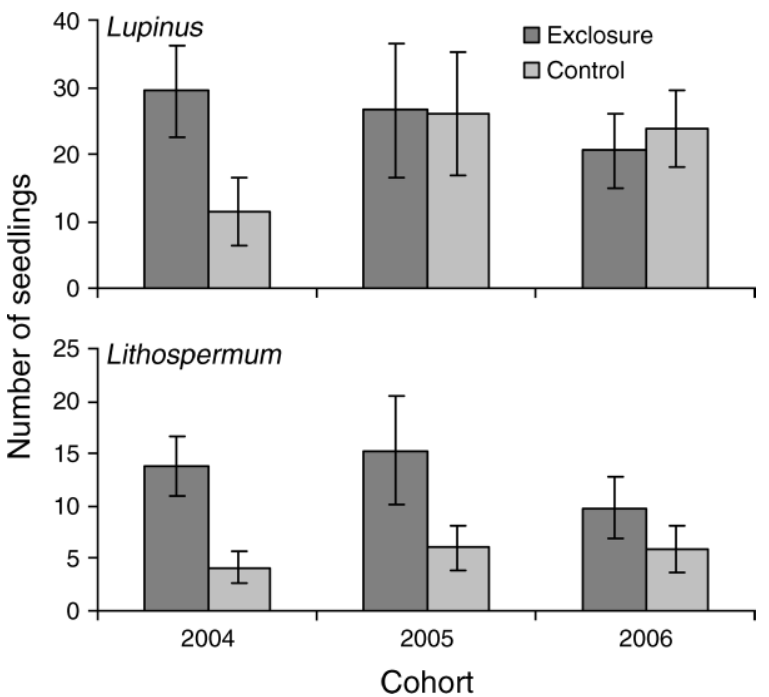

FIG. 3. Number of seedlings (mean $\pm \mathrm{SE}$ ) emerged in the spring following seed addition (for Lupinus), or two years following seed addition (for Lithospermum). The 2004 data are as in Fig. 1 for 100-seed plots.

both Lupinus sericeus and Lithospermum ruderale, suggesting that post-dispersal seed predation by small mammals can substantially decrease the abundance of early life stages of these plants. Furthermore, gains in plant abundance from protecting seeds from deer mice were still evident and significant three years after seed addition, indicating the potential for lasting impacts of seed predation (Fig. 1). These results, along with other studies that have shown increases in seedling emergence with protection from small-mammal seed predation (Edwards and Crawley 1999, Howe and Brown 2000, Maron and Kauffman 2006, Pearson and Callaway 2008) contrast with the expectation that seed predators consume a "doomed surplus" of seeds unlikely to germinate or establish (Hulme 1998, Crawley 2000). Unlike studies in which initial differences caused by rodent seed predation have faded with time due to density-dependent mortality (Edwards and Crawley 1999, Howe and Brown 2001), we found no evidence of density-dependent mortality rates over similar or longer time spans, even though seedlings occurred at extremely high densities in some of the plots (many high-density seed addition plots had over 50 seedlings per $0.25 \mathrm{~m}^{2}$ ). Clearly at some point these high densities will lead to a decrease in plant performance or survival. However, these plants are sparsely distributed in their natural populations in this area, suggesting that their populations could see significant increases in abundance due to release from rodent seed predation before density dependence would cause large declines in plant performance.

These experiments also showed higher numbers of seedlings in plots receiving higher seed densities (Figs. 1 and 2). This positive relationship between seed input and seedling emergence was evident in both exclosure and control plots, though the number of seedlings was lower in the controls, where seeds had been exposed to smallmammal predation. There was no interaction between seed treatment and small-mammal treatment, indicating a consistent rate of return of seedlings per remaining seed within each small-mammal treatment (protected or exposed). Similar to many studies reviewed in Clark et al. (2007), we saw what was considered a relatively low effect size from seeds added, with an average of $0.2-0.3$ seedlings per seed inside of small-mammal exclosures and $0.05-0.2$ seedlings per seed outside of smallmammal exclosures (Appendix). However, this effect did lead to a two- to fivefold increase in seedlings between the lower and higher seed addition densities and an almost threefold increase in seedlings when plots were protected from seed predation. Recruitment of seedlings along demography transects through natural populations accessible to small mammals is quite low, well below the densities recorded in even the lowest-density seed addition subplots (M. Bricker, unpublished data). This suggests that in these areas, Lupinus and Lithospermum populations are limited by low seed availability due, in part, to seed predation by small mammals.

The length of this study allowed us to separate the effects of different guilds of small mammals on plant establishment. Because we followed plants from the 2004 cohort of seeds for three years, the small-mammal exclusion treatments protected plants from small-mammal herbivory as well as granivory. The frequency of censuses recording deaths of seedlings and young plants over the spring and summer made it possible to examine whether mortality rates due to herbivory by small
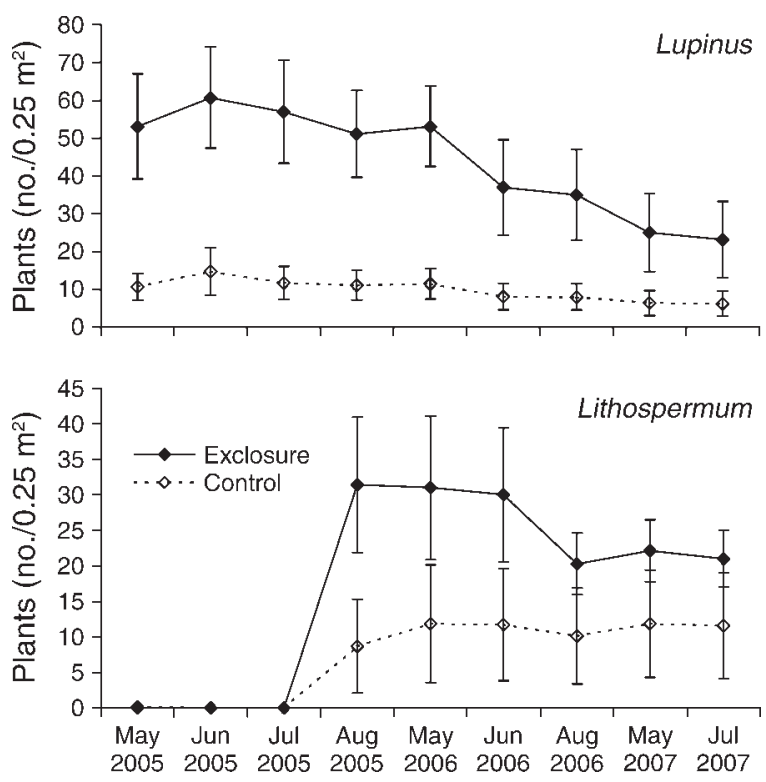

FIG. 4. Number of plants (mean $\pm \mathrm{SE}$ ) in seed addition plots at consecutive census points over the three years following seed addition. These graphs show the seed addition plots receiving the maximum number of seeds for each species: 200 seeds per $0.25-\mathrm{m}^{2}$ subplot for Lupinus and 300 seeds for Lithospermum. 
mammals (such as voles and ground squirrels) affected plant establishment. Mortality rates in and out of the exclosures did not differ for either species in this experiment, indicating that herbivory from small mammals was not a significant source of mortality among seedlings and young plants (Fig. 4). Although both granivorous and herbivorous small mammals have been shown to impact community composition and plant abundance (Edwards and Crawley 1999, Howe and Brown 2000, 2001, Howe and Lane 2004, Howe et al. 2006, Kauffman and Maron 2006), in this study it appears that granivory, rather than herbivory, was the primary driver of the differences in plant abundance in and out of the small-mammal exclosures.

Our results demonstrate several important considerations for seed addition studies. First, post-dispersal seed predators have the potential to lower the apparent evidence of seed limitation where they have access to added seeds. This supports the argument that seed addition experiments should explicitly consider or manipulate seed predation (Turnbull et al. 2000, Clark et al. 2007) particularly for plants with large or attractive seeds. If levels of seed limitation inferred from standard seed addition experiments were used to assess the potential for seed consumers to affect these populations, the low relationship between seed density and seedling emergence outside of the small-mammal exclosures would lead to an underestimation of the degree of seed limitation and the capacity for seed predators to alter seedling abundance. The results inside of the exclosures, however, indicate that when protected from seed predators, these populations experienced strong seed limitation (Fig. 1). These results also highlight the importance of following seed addition experiments beyond seedling emergence. For the Lithospermum seeds, for example, which were mostly dormant for the first year after seed additions, a standard interpretation might have been that these populations were strongly site limited, requiring particular, extremely rare, microsite conditions in order to germinate. Following these seed additions over multiple years showed that, though seedling emergence was delayed for a large proportion of the seeds, there was seed limitation in the population overall, as the number of emerging seedlings increased with increasing seed input.

Visible and significant differences three years after seed additions show that the effects of small mammals and seed numbers are not fleeting differences quickly swamped out by density-dependent processes or spatiotemporal variation (Fig. 1, lower panels). In fact, Lupinus plants added as seeds in 2004 have now begun to flower and set seed at some sites. Although most of the plants are still below the average size of adults in the surrounding populations, some have reached reproductive size, indicating that these initial differences can persist and affect overall plant abundance. The fact that both of these species occur at low to moderate densities in the areas surrounding the seed addition experiments (Lithospermum occurring in an average of $6.7 \%$ of vegetation survey subplots, and Lupinus in an average 23\%) (J. Maron and D. Pearson, unpublished data) suggests that small-mammal seed predation may be one factor limiting their abundance. This is supported, as well, by results from population projection analyses incorporating these experimental results into demographic matrix models, in which seed predation decreases the population growth rate for Lithospermum (M. Bricker, unpublished data).

Both Lupinus and Lithospermum, despite varied adult life histories, have very large and similarly sized seeds. Their uniform response to seed addition and rodent exclusion supports the idea that large-seeded species will be particularly vulnerable to the effects of seed loss from small-mammal granivory. Our results indicate that for large-seeded species, small-mammal seed predation has strong potential to decrease adult plant abundance. This study adds to work in other systems that have shown small-mammal seed predation to affect the abundance of plants in systems such as deserts (Inouye et al. 1980, Davidson et al. 1984, Brown and Heske 1990), dunes (Maron and Kauffman 2006), and restoration plantings (Howe and Brown 2000, 2001, Howe et al. 2002). Our results demonstrate that small-mammal seed predation can lower plant abundance even in communities with denser cover, such as grasslands.

\section{ACKNOWLEDGMENTS}

We thank the Montana Fish, Wildlife and Parks, the U.S. Fish and Wildlife Service, and the U.S. Bureau of Land Management for allowing us to conduct experiments on their protected sites. We appreciate field help from Cedar Brant, Christen Kiser, and Adam Leiberg. Jennifer Williams's statistical advice was invaluable, and the manuscript benefited greatly from comments and discussion with members of the Maron and Crone labs at the University of Montana. M. C. Bricker was supported during the course of this study by funds from the NSF EPSCoR grant for the state of Montana (EPS0346458) and by an ECOS fellowship from an NSF GK-12 grant (03-38165) to the University of Montana. This project was partially supported by grants to J. L. Maron from the National Research Initiative of the USDA Cooperative State Research, Education, and Extension Service (grant number 2005-35101-16040) and grants from McIntire-Stennis and the Bureau of Land Management.

\section{Literature Cited}

Brown, J. H., and E. J. Heske. 1990. Control of a desertgrassland transition by a keystone rodent guild. Science 250: 1705-1707.

Brown, J. H., and J. C. Munger. 1985. Experimental manipulation of a desert rodent community: food addition and species removal. Ecology 66:1545-1563.

Brown, J. H., O. J. Reichman, and D. W. Davidson. 1979. Granivory in desert ecosystems. Annual Review of Ecology and Systematics 10:201-227.

Celis-Deiz, J. L., R. O. Bustamante, and R. A. Vasquez. 2004. Assessing frequency-dependent seed size selection: a field experiment. Biological Journal of the Linnean Society 81: 307-312.

Clark, C. J., J. R. Poulsen, D. J. Levey, and C. W. Osenberg. 2007. Are plant populations seed limited? A critique and meta-analysis of seed addition experiments. American Naturalist 170:128-142. 
Crawley, M. J. 2000. Seed predators and plant population dynamics. Pages 167-182 in M. Fenner, editor. Seeds: the ecology of regeneration in plant communities. CABI, New York, New York, USA.

Davidson, D. W., R. S. Inouye, and J. H. Brown. 1984 Granivory in a desert ecosystem: experimental evidence for indirect facilitation of ants by rodents. Ecology 65:1780 1786.

Edwards, G. R., and M. J. Crawley. 1999. Rodent seed predation and seedling recruitment in mesic grassland. Oecologia 118:288-296.

Eriksson, O., and J. Ehrlen. 1992. Seed and microsite limitation of recruitment in plant populations. Oecologia 91:360-364.

Halpern, S. L., and N. Underwood. 2006. Approaches for testing herbivore effects on plant population dynamics. Journal of Applied Ecology 43:922-929.

Harper, J. L. 1977. Population biology of plants. Academic Press, San Diego, California, USA.

Hoffman, L. A., E. F. Redente, and L. C. McEwen. 1995 Effects of selective seed predation by rodents on shortgrass establishment. Ecological Applications 5:200-208.

Howe, H. F., and J. S. Brown. 2000. Early effects of rodent granivory on experimental forb communities. Ecological Applications 10:917-924.

Howe, H. F., and J. S. Brown. 2001. The ghost of granivory past. Ecology Letters 4:371-378.

Howe, H. F., J. S. Brown, and B. Zorn-Arnold. 2002. A rodent plague on prairie diversity. Ecology Letters 5:30-36.

Howe, H. F., and D. Lane. 2004. Vole-driven succession in experimental wet-prairie restorations. Ecological Applications 14:1295-1305.

Howe, H. F., B. Zorn-Arnold, A. Sullivan, and J. S. Brown 2006. Massive and distinctive effects of meadow voles on grassland vegetation. Ecology 87:3007-3013.

Hulme, P. E. 1993. Post-dispersal seed predation by small mammals. Symposium of the Zoological Society of London 65:269-287.

Hulme, P. E. 1994. Post-dispersal seed predation in grassland: its magnitude and sources of variation. Journal of Ecology $82: 645-652$
Hulme, P. E. 1998. Post-dispersal seed predation: consequences for plant demography and evolution. Perspectives in Plant Ecology, Evolution, and Systematics 1:32-46.

Inouye, R. S., G. S. Byers, and J. H. Brown. 1980. Effects of predation and competition on survivorship, fecundity, and community structure of desert annuals. Ecology 61:13441351.

Kauffman, M. J., and J. L. Maron. 2006. Consumers limit the abundance and dynamics of a perennial shrub with a seed bank. American Naturalist 168:454-470.

Manson, R. H., and E. W. Stiles. 1998. Links between microhabitat preferences and seed predation by small mammals in old fields. Oikos 82:37-50.

Maron, J. L., and M. J. Kauffman. 2006. Habitat-specific impacts of multiple consumers on plant population dynamics. Ecology 87:113-124.

Maron, J. L., and E. L. Simms. 1997. Effect of seed predation on seed bank size and seedling recruitment of bush lupine (Lupinus arboreus). Oecologia 111:76-83.

Mittelbach, G. G., and K. L. Gross. 1984. Experimental studies of seed predation in old-fields. Oecologia 65:7-13.

Pearson, D. E., and R. M. Callaway. 2008. Weed-biocontrol insects reduce native-plant recruitment through second-order apparent competition. Ecological Applications 18:1489-1500.

Poulsen, J. R., C. W. Osenberg, C. J. Clark, D. J. Levey, and B. M. Bolker. 2007. Plants as reef fish: fitting the functional form of seedling recruitment. American Naturalist 170:167182.

Reader, R. J. 1993. Control of seedling emergence by ground cover and seed predation in relation to seed size for some oldfield species. Journal of Ecology 81:169-175.

Reichman, O. J. 1979. Desert granivore foraging and its impact on seed densities and distributions. Ecology 60:1085-1092.

SAS Institute. 2004. PROCMIXED version 9.1. SAS Institute, Cary, North Carolina, USA.

S-PLUS. 2007. S-PLUS version 8.0. Insightful Corporation, Seattle, Washington, USA.

Turnbull, L. A., M. J. Crawley, and M. Rees. 2000. Are plant populations seed-limited? A review of seed sowing experiments. Oikos 88:225-238.

\section{APPENDIX}

Tables showing rates of cumulative emergence, establishment, and mortality for seed addition plots by seed density and smallmammal exclusion treatment (Ecological Archives E091-008-A1). 